\title{
Dar mekânda geniş zamanlar: Sabahattin Ali’nin anlatılarında (öykülerinde) mahpushane izleri
}

\section{Ahmet KOÇAK'}

\begin{abstract}
APA: Koçak, A. (2019). Dar mekânda geniş zamanlar: Sabahattin Ali'nin anlatılarında (öykülerinde) mahpushane izleri. RumeliDE Dil ve Edebiyat Araşttrmaları Dergisi, (Ö5), 158-166. DOI: 10.29000/rumelide.606103.
\end{abstract}

\section{$\ddot{O} \mathbf{z}$}

Bütün varlıkların üzerinde yaşadığı yer olarak tanımlanan mekân, insan için de çok şey ifade etmektedir. Çünkü insanoğlu var olandan beri bir mekân üzerinde yaşamakta ve ona şekil verme uğraşı içinde bulunmaktadır. Başlangıçtan bugüne kadar coğrafya, doğal ve tarihsel olaylar, siyasi ve ekonomik sebepler, bilimdeki gelişmeler, yeni icatlar ve teknolojik gelişmeler insanoğlunun mekânla ilişkisinde zamanla değişikliklere sebep olsa da insan - mekân ilişkisini değiştirememiştir. Michel Facoult'un "Başka Mekânlara Dair" adlı kuramsal eserinde de işaret ettiği gibi Ortaçağda, Rönesans'ta ve sonrasında modern dönemde mekân anlayışı farklıdır. Hatta buna post-modern dönemi de eklemek gerekir. Modern Türk edebiyatının önemli simalarından Sabahattin Ali’nin genelde anlatılarında özelde ise öykülerinde, mekânın kapalı - dar ve açık-geniş şekilde kullandığı görülür. Mahpushane devlet otoritesi ile inşa edilmiş kapalı - dar mekânlardır. Sabahattin Ali şu ya da bu sebeple hapse düşmüş ve bu mekânları deneyimleyerek yaşamış birisidir. Bu makalede roman, öykü, şiir gibi farklı türlerde eserler vermiş Türk edebiyatının önemli isimlerinden Sabahattin Ali’nin öykülerinde genelde mekân, özelde ise hapishane konusunun nasıl işlendiği, yazarın bir şekilde kaldığı bu mekânların eserlerine nasıl yansıdığı örneklerle açıklamaya çalışılacaktır.

Anahtar kavramlar: Sabahattin Ali, anlatı, hikâye, roman, kurgu.

\section{Extensive time in narrow spaces: The prison in Sabahattin Ali's narratives (stories)}

\begin{abstract}
A space, defined as a place where all beings live, means a lot for mankind because they have been living in a space and they have been in an effort to shape it since their existence. Although geography, natural and historical events, political and economic reasons, advances in science, new inventions and technological developments have caused changes in the relationship of mankind and space since the beginning, they haven't been able to change the relationship between mankind and space. As Michel Foucault points out in his theoretical work titled "Of Other Spaces", the concept of space is different in the medieval age, renaissance and modern era. The post-modern era should also be included. It is seen that Sabahattin Ali, one of the important figures of the modern Turkish literature, depicts the space as closed-narrow and open-wide in his narratives and stories. Prisons are closednarrow spaces built by the state authority. Sabahattin Ali somehow ended up in prison and experienced the life in these places. This paper tries to explain the way Sabahattin Ali, who is considered as one of the important figures of the Turkish literature and produced works in various
\end{abstract}

1 Doç. Dr., İstanbul Medeniyet Üniversitesi, Edebiyat Fakültesi, Türk Dili ve Edebiyatı Bölümü (İstanbul, Türkiye), kocakahmet70@hotmail.com, ORCID ID: 00oo-0002-0033-4188 [Makale kayt tarihi: 16.07.2019-kabul tarihi: 19.08.2019; DOI: 10.2900o/rumelide.606103] 
genres such as novel, story, and poetry, depicts the space in general and the prison in particular, and the way he reflects these places, he somehow ended up in, in his works by means of examples.

Keywords: Sabahattin Ali, narrative, story, novel, fiction.

\section{Giriş}

Sabahattin Ali Türk edebiyatında hikâye, roman şiir ve oyun türünde eser vermiş cumhuriyet devrinin çok yönlü yazarlarından birisidir. Özellikle toplumsal hayatın yansıtılmasında çok başarılı olmuş hikâye ve romanlarıyla öne çıkmıştır. Onun öykülerinde hapishane izlerine geçmeden önce kısaca hayat hikâyesinde bu konunun izlerini belirlemek konunun daha iyi aydınlatılmasına yardımcı olacaktır.

Aslen Karadenizli bir ailenin çocuğu olan Sabahattin Ali, Bulgaristan'da Gümülcine’ye bağlı Eğridere kasabasında doğar. ${ }^{2}$ Nüfus kaydı ise Ayvalık'tadır. Yedi yaşında Üsküdar Doğancılar'daki Füyuzat-ı Osmaniye Mektebine devam ederken babasının tayininin çıması sonucu ailecek Çanakkale'ye taşınırlar. Burada o İbtidai Mektebine devam eder. 1922 - 1923 ders yılında ise Balıkesir'deki Muallim Mektebinde eğitim görür. 3

Sabahattin Ali’nin ilk memuriyeti 1927 yılında Yozgat merkezdeki bir ilkokulda öğretmenlikle başlar.4 Bir yıl sonra devletin açtığı bir sınavı kazanarak Almanya'ya gider. Almanya yolculuğu Sirkeci'den kalkan bir trenle Edirne, Sofya, Belgrat, Budapeşte, Prag ve Dresten üzerinden Berlin'dir. ${ }^{5}$ Almanya'da Maksim Gorki, Turgenyev, E. A. Poe, Mauppassant, Hoffmann, Heinrich Von Kleist, Knut Hamsun gibi isimleri okur. Almanya serüveni iki yıla ulaşmadan tamamlanır. ${ }^{6}$

\section{Hayat çizgisinde hapishane izleri}

Sabahattin Ali, 1930 yllnnda Almanya'dan döndükten kısa bir süre sonra Bursa Orhaneli’nde öğretmenlik görevinde bulunur, ardından Aydın Ortaokuluna Almanca öğretmeni olarak atanır.7 Burada kominizim propagandası yaptığı gerekçesiyle hakkında soruşturma açlır. Mayıs - Eylül 1931 yılında yaklaşık dört ay hapiste kalır. Burada Kuyucakl Yusuf ve "Candarma Bekir"deki Halil Efe ile tanışır, yazacağı eserlere malzeme toplar. ${ }^{8}$

Hakkında verilen beraat kararından sonra Konya Orta Okuluna Almanca öğretmeni olur. Hapishane hayatıyla ikinci defa burada yüz yüze gelir. Burada yazdığı bir şiirle on dört ay hapse mahkûm olur9 ve 22 Aralık 1932 yılında tutuklanır. ${ }^{10}$ Yaklaşık altı ay sonra da adına "Gurbet Hapishanesi" de denilen Sinop Hapishanesine sürülür. Sinop cezaevi deniz kıyısında nemli, rutubetli deniz dalgalarının sürekli duvarlarını dövdüğü bir mekândır.11 29 Ekim 1933’te cumhuriyetin onuncu yllı vesilesiyle tahliye edilir. Yazar hapiste on ay yedi gün kalmıştır. Bundan sonra da mahkeme kapılarında bulunması çeşitli vesilelerle eksik olmaz.

\footnotetext{
Cevdet Kudret, "Sabahattin Ali Konusunda Aydınlığa Doğru”, Varlkk, S. 671, 1 Haziran 1966, s.7.

Ramazan Korkmaz, Sabahattin Ali İnsan ve Eser, Kesit yay. İstanbul 2016, s. 22-27.

Reşit Mazhar Ertüzün, Sabahattin Olayının Gerçeği (Benim Bildiğim Sabahattin Ali), Gür yay. İstanbul 1985, s. 13.

Sabahattin Ali, "Mufassal Cermenistan Seyahatnamesi", Sabahattin Ali, hz. Filiz Ali - Atilla Özkırıml, De Yayınevi, İstanbul 1986, s. 386-392.

Asım Bezirci, Sabahattin Ali Hayatı-Hikâyeleri-Romanları, Oluş Yay. İstanbul 1974, s. 19 ; Korkmaz, s. 35.

Asım Bezirci, Sabahattin Ali Araştrma/Eleştiri, Gözlem Yay. İstanbul 1979, s. 24.

Korkmaz, age, s.37-38.

Kemal Sülker, Sabahattin Ali Dosyası, Ant Yayınları, İstanbul 1968, s. 15.

Sabahattin Ali, İki Gözüm Ayşe, s.55-56.

Berin Taşan, "Sabahattin Ali Sinopta”, Soyut, S.87, Ocak 1976, s.44-45.
} 
Türk Dil Kurumuna üye olarak atanması üzerine Nihal Atsız onun aleyhinde yazılar kaleme alır, kampanya başlatır. Bunun üzerine soruşturmalar geçirir, mahkemelere çıkartılır. ${ }^{12}$ Marko Paşa'da yayımlanan "Topunun Kökün Kibrit Suyu”, “Kenan Döner Komedisi” yazılarında Cemil Sait Barlas'a hakaret ettiği gerekçesiyle dört ay hapse mahkûm olur. Yine gazeteci yazar Falih Rıfkı Atay’a hakaret ettiği gerekçesiyle de yedi ay, toplamda on bir ay cezaya çaptırılır. 1947 yılında önce İstanbul cezaevine, sonra da 11 Haziran 1947 tarihinde Üsküdar Paşakapısı cezaevine nakledilir. ${ }^{13} 31$ Mart 1948 tarihinde İstanbul'dan Bulgaristan'a geçmek için bindiği insan kaçakçılarına ait bir kamyon, dört, beş ay sonra sinır boyunda bir cesedin çobanlar tarafından bulunmasıyla son bulur. ${ }^{14}$ Dolayısıyla Rumeli coğrafyasında hayata gözlerini açan Sabahattin Ali’nin hayata gözlerini kapaması da yine bu topraklardadir.

\section{Hapishane yoluna döşenen taşlar}

Sabahattin Ali’nin özellikle öyküleri biyografik bir okumaya tabi tutulduğu zaman hayat çizgisinin metinlerde nasll şekillendiği görülebilir.

"Bir Skandal" başlığı altında on beş bölümden oluşan bu hikâyesinin daha ilk cümlesinde şöyle der: "Muallim olarak geldiğim şehir Orta Anadolu'nun bozkırlarında bir cilt yarası gibi intizamsız, karışık ve kirli uzanıyor, yayllyordu.” (2014: 76). Yazarın bu şehre geliş sebebi âşık olduğu insanı geride bırakmasıdır: "Şiddetle aşıktım ve bana aşı olmayı aklından bile geçirmeyen sevgilimi İstanbul'da bırakmıştım.” (2014:76). Bu sebeptendir ki yazar şehre bir türlü ısınamaz, çünkü gönlüyle beraber aklı da geldiği yerde yani İstanbul'da kalmıştır. Çünkü bu şehirde Selmin diye bir kıza âşıtır. Anlatıcının Orta Anadolu'da bir şehre öğretmen olarak geldiği zaman ruh dünyası bu vaziyettedir. Asıl sorunlar burada yani İstanbul'dan uzakta kaldığı taşra hayatında başlar. Geldiğinin ertesi akşamı gece kulübü olarak adlandırılan ancak Anadolu'da bir kahvehane olan mekânda şehrin münevverleriyle oturur. $\mathrm{O}$ gece alafranga müzikten, şehrin yeni planından, bunun yanında bir mühendis uzun uzun edebiyattan, bir doktor bahçesinde yetiştirdiği çiçeklerden ve sonra dedikodu kabilinden şehirdeki olaylardan bahsedilir. Kısaca taşrada aydın insanların bulunduğu mekânlarda bile hayat, dedikodu üzerine kurulu gibidir.

Şehirde bazı aileler kendi aralarında toplanarak gece eğlenceleri düzenlemektedirler. Yazar da tombala oynanıp dedikodu yapılan, bazen de küçük çapta poker oyunu oynanan bu ortamlara katılır. Kadınlar olduklarından olağanüstü görünmeye, erkekler basitlikte birbiriyle yarışır vaziyettedirler. Bir erkeğin, hele bekâr bir erkeğin bu ortamlara katılması yazarın ifadesiyle "mebus intihap edilmekten" daha güçtür (2014:80).

Yazarın Anadolu'da ilk çatışması ya da ilk görüş ayrıllğı onu anlayacak daha doğrusu anlaması beklenen tabakadan gelmiştir. Anlatıcının Anadolu'da gördüğü, aynı ortamlarda bulunduğu iyi eğitim görmüş doktor, avukat, mühendis, muallim gibi okumuş yazmış insanlar vardır. Ancak bu insanlar aldıkları eğitimi bir fikir ihtiyacından ziyade, karnını doyurmak, iyi giyinmek, iyi yaşamak "güzel karı alabilmek" için yapmışlardır. Bunlar dünyaya, vatana, millete, devlete dair en ufak bir görüş sarf etmezler, "suya sabuna dokunmamaya" azami derecede riayet ederler.

Anadolu'da yine bir aile toplantısına bir arkadaşının davetiyle katılan anlatıcı, orada konuşmaları dinleyip, epey sustuktan sonra konu köylüye, köylünün efendi olmasına gelince söze karışır: "Efendi diye

Nihal Atsız, "Başvekil Saraçoğlu Şükrü’ye İkinci Açık Mektup”, Orhun, S.16, 1 Nisan 1944, s.2-3.

Filiz Ali - Atilla Özkırıml, Sabahattin Ali, s.264-265.

Korkmaz, age, s. 56-62. 
başkasını çalıştıran ve ona hükmünü geçirenlere derler, çalışıp çabalayıp en sonunda elindekini bir hiç mukabilinde verenlere değil...” (2014:81). Bu çıkıştan sonra mesele derinlemesine tartışlmaya başlanır. Bu ortamda "köylü milletin efendisidir" sözünün arkasında olanlar, kurulu sistemi, sloganik ifadenin ötesine geçmeyen bir anlayışın savunucularıdır. Anlatıcının şehirli vergi verir, karşılı̆̆ında caddesi, sokağı yapılır, temizlenir, çocukları için parklar düzenlenir, ancak iş köylüye gelince, köylü yolunu kendisi yapar, sokakları karanlıktır, mektep köylerde olmadığı için eğitim de alamayacak durumdadır. Bunlardan sonra yazar, "Köylü milletin efendisidir!" cümlesinin birer morfinden başka bir şey olmadığını ifade eder. Gece bu tartışmanın yaşandığı ortamda ayrı bir yerde bulunan kadınlar da konuşulanlara dikkat kesilmişlerdir. Ancak erkekler gibi kadınlar da yazara karşı olumsuz bir tavır içindedirler. Sadece bunlar arasında genç bir kız anlatıcının fikirlerini benimsemiş görünmektedir. Bu sohbet ortamı dağıldığı zaman, yazarı bu ortama getiren arkadaşı da yazara karşı çıkmış, onun anlattığı düşünceleri yüzeysel anlamış, daha doğrusu "Açıktan açığa muhalefet yaptığını" söylemiştir. Yazarın "Abdülhamit zamanında değiliz ya, tabii düşündüğüm ve doğru bulduğum şeyleri açlkça söyleyeceğim, söyleyeceklerim yalan mıydı, sen ondan bahset?” sualine yalan olmadığını ancak alttan mesajın sisteme verildiğini ima da ederek, "Köylüyü müdafaanın filan ne lüzumu var efendim?" diyerek konuyu geçiştirir. (2014:83).

Derin meselesi, yarınlar için planı, bir davası olan yazarın bu Anadolu şehrinde kısa süre canı sıkılmaya başlar. "Açık saçık iki laf söylemeye imkân yok, derhal çehreler değişiyor ve birisi kulağıma eğilerek: 'Bırak bu lafları Allah aşkına, ortalığı düzeltmek sana mı kaldı" ya da "Hakkın var, var ama, bunları söylemenin sırası değil!" şeklinde ikazlar başlamıştır (2014:85). Yazar satır aralarında kendisine "Doğru düşünüyorsun ama, bunları söyleme!" diyenleri "adam adeta namussuzluk tavsiye ediyor" şeklinde algılar (2014:85). Anadolu'daki bir şehirde fikirlere, kanaatlere hürmet etmeyi bilmeyen bu insanlar, bunu lüzumsuz ve manasız bulurlar. Hatta bir kısmı fikir ve kanaat sahibi olmayı, lüzumsuz ve manasız değil, aynı zamanda tehlikeli ve ayıp bir şey hatta "cemiyetin sükunetine bomba koymaya gelmiş bir anarşist nazarıyla bakar"lar (2014:85). Bu ortamdan sıkılan yazar, kendisini kenara çeker, onun en iyi ahbabı kitapları ve kitaplarına dolap yaptırdığı marangoz Fazıl'dır. Ancak bu kez de "kendi ayarında olmayan” insanlarla düşüp kalktığı gerekçesiyle hakkında dedikodular çıkar. Hatta mektep müdürü bir gün "Nurullah Bey, daha gençsiniz, tecrübesizsiniz, ateşlisiniz, ben sizin ağabeyiniz sayılırım, hani aklınıza bir şey gelmesin, fakat biraz daha ağır davranınız” gibi ifadelerle uyarır. (2014: 86). Yazar, müdür beyin anlattıklarına kızıp, düşüp kalktığı birkaç kişinin onların da seviyelerinin belli oluğu, en azından bu insanların kendi seviyelerinin farkında olduğu, kimsenin hakkına tecavüz etmediğini anlatır. Ancak sonunda müdür bey "Siz bilirsiniz" diyerek sözü kapatır, aslında bu yazarın ifadesiyle "Sen görürsün” demektir (2014:87).

Yukarda geçen diyaloglardan aydın köylü ayrımının en canlı tasvirleri çizilir. Anadolu’yu aydınlatmak üzere gelen okumuş yazmış takım, kendi küçük dünyalarında yaşamakta hayattan zevk almanın dışında bir konu düşünmemektedir. Halktan ve köylüden kopuk, kendi küçük dünyaları içinde sefa sürüp gitmektedirler. Sabahattin Ali burada diğer aydınlardan ayrılmakta, kendisine okuması yazması olmayan, ancak saf düşüncelerle yerel kalmaya devam eden yerli insanlarla diyalog kurmaya devam etmiştir. Ancak dönemin aydın kesiminde bu da sorgulanır duruma gelmiştir.

Sabahattin Ali'nin Anadolu'da arkadaş olduğu ancak sonra dedikodular ortaya çıkınca uzaklaştığı isim ise, Şukufe'dir. Şukufe ile arkadaş olan Nurullah (anlatıcı), onun bu arkadaşlı̆̆ı daha ileri taşıma düşüncesinde olduğunu ve bunun için de etrafta dedikodular yaydığını çevresindeki arkadaşlardan duyar. Hikâyenin sonunda Anadolu'da hakkında çıkan yalan yanlış haberler ve dedikodularla İstanbul'a dönmek zorunda kalır. Dönerken de sadece kitaplık yaptırdı̆̆ı, Anadolu'daki aydın kesimin hor hakir ve 
küçük gördüğü marangoz Fazıl vardır. Sabahattin Ali’nin öyküsünün merkezine yerleştirdiği Marangoz Fazıl, Anadolu'da amir, memur olarak çalışan okumuş yazmış kişilerden daha samimi, daha içtendir. Yazarın taşrada neredeyse tek onunla samimi olması, okuması yazması olmayan Anadolu insanının, köylüsünün bozulmamışlı̆ına işaret edilirken, diğer yandan da cumhuriyet bürokrasinin ortaya çıardığı memur tiplerinin toplumdan ne kadar uzak olduğu eleştirisi de yapılır.

\section{Dar mekânlar geniş zamanlar}

Hapishaneler labirent gibi dar mekanlardır. Tarih boyunca suçlulara ev sahipliği yapmış bu mekânlar dinlere ve kültürlere göre de değişik mekânlar olmuştur Hamam, kilise, medrese, cami gibi dini ve tarihi mekânların bu amaçla kullanıldığı görülür (Fındıklı, 2019: 323). Ladovic Janvar, "İnsanı ezen mekân tarzı" ve burayı anlatan metinleri "Labirent temalı hikâyeler" olarak niteler. Sabahattin Ali’nin altmış hikâyesinden yirmi üçü yani neredeyse üçte birden fazlası böyledir. Bu arada o sadece öykülerin de değil şiirlerinde de hapishane ve buradan kurtulma, özgürlüğe kavuşma temalarını işlediği hatırda tutulmalıdır. ${ }^{15}$ Marcel Proust, Mahpus romanının daha girişinde hapishanede mahkûm olarak yatan bir insanın psikolojini, hayata bakışını birkaç satırda özetleyiverir. Bu satırlarda, duvar, gün ışı̆̆ı, rutubetli bir hava ve tabiattaki bazı şeyleri takip ederek, gözlemleyerek olması muhtemel gelişmeleri tahmin etme gibi mahkûmun ruh dünyasının farklı yönleri çizilir.

"Sabahları, yüzüm hala duvara çevriliyken, penceredeki ağır perdelerin tepesinden gün ışı̆ıının rengini daha görmeden, havanın nasıl olduğunu hemen anlardım. Bana bu konuda sabahın ilk sesleri bilgi verirdi; hava rutubetliyse, sesler bana boğularak, çarpılarak ulaşırdı; ferah, buz gibi ve berrak sabahlardaysa, çınlayan boş havada sesler birer ok gibi titreşirdi; daha ilk tramvay geçerken, tekerlek seslerinden, soğuk bir yağmur mu yağdığını, yoksa sabahın masmavi bir gökyüzüne doğru mu yol aldığını anlardım." (Proust, 2001: 1)

Sabahattin Ali 1935 yllında kaleme aldığı "Bir Şaka" başlıklı öyküsünde hapishaneye girişini şöyle anlatır: "Konya hapishanesine ilk girdiğim gün Cavit Beyle tanıştım. Beni ihtilattan menederek başgardiyanın yattı̆̆ı odaya kapamışlardı. Gece olunca nöbetçi gardiyan kapımı açarak beni 'yüze gelen mahpuslar' koğuşuna götürdü. Gaz lambalarının asılı durduğu duvarların kenarlarındaki minderlere oturarak yavaş yavaş konuşan, mangalları karıştıran, fasulye ayıklayan, Kur'an okuyan mahpusların arasından geçerken hepsi süratle yerlerinden kalkıyorlar, 'geçmiş olsun beyim!' diye mırıldanıyorlardı." (Bezirci, 1974: 23).

Sabahattin Ali, mahkûmlardan birisinin yaptığı şakaya inanarak İstanbul'a gideceğini beklerken, Sinop cezaevine nakledildiğini öğrenir. Bu onda ilk başta büyük bir yıkıma sebep olur. "Ve trene bindikten sonra jandarmanın elindeki sevk kâğıdına bakınca gördüm ki, İstanbul müddeiumumiliğine, Sinop hapishanesine gönderilmek üzere teslim edilecektim. Bunu okuyunca çöker gibi oldum. Bir deniz kenarında yapayalnız duran bir hapishane gözlerimde canlandı ve içinde bir tek bile tanıdığım olmayan o yalı şehrini düşündüm... Gurbet hapishanesi! Dedim...” (Bezirci, 1974: 23-24).

"Duvar" öyküsünde hapishane sıradan bir mekân olmanın çok ötesinde anlamlar kazanmıştır: "Uzun zamanlar deniz kenarında ve surlar içindeki bir hapishanede kaldım. Kalın duvarlara vuran suların sesi taş odalarda çınlar ve uzak yolculuklara çağırırdı. Tüylerinden sular damlıyarak surların arkasından

Sabahattin Ali’nin Dağlar ve Rüzgar kitabında yer alan ve 1933 yılında yazılan "Gurbet Hapishaneleri” ve Hapishane
Şarkısı şiirleri buna örnektir. Bk. Sabahattin Ali, Bütün Şiirleri: Dağlar Ve Rüzgar, Kurbağanın Serenadı, Öteki Şiirler, Şarkısı" șïrleri buna örnektir. Bk. Sabahattin Ali, Bütün Şiirleri : Dağlar
hz. Atilla Özkırımlı, İstanbul: Yapı Kredi Kültür Sanat Yayıncllk, 1999. 
yükseliveren deniz kuşları demir parmaklıklara hayretle gözlerini kırparak bakarlar ve hemen uzaklaşırlardı.

Bir mahpusu dünya ile hiç alakası olmayan bir zindana kapamak ona en büyük iyiliği yapmaktır. Onu en çok yere vuran şey, hürriyetin elle tutulacak kadar uzak olduğunu bilmektir. On adım ötede en büyük hürriyetlere götüren denizi dinlemek ve sonra aradaki kalın kale duvarlarına gözlerini dikerek bakmăga, denizi yalnız muhayyilede görmeye mecbur kalmak az azap mıdır?” (Bezirci, 1974: 24)

$\mathrm{Bu}$ arada sadece Sabahattin Ali'nin değil, o dönemde siyasi sebeplerle pek çok ismin ülkenin farklı yerlerinde hapis yattıkları ve mahpushane ortamını eserlerine taşıdıkları hatta burada gördükleri kişileri eserlerine taşıdıkları bilinmektedir. Bu örneklerden birisi de Kemal Tahir'in Kelleci Mehmet romanıdır. ${ }^{16}$

Sabahattin Ali’nin ilki Aydın'da 1931, ikincisi Konya'da 1932 ve üçüncüsü İstanbul'da 1948 yllında tutuklandığı, bir süre, Aydın, Konya, Sinop ve İstanbul mahpushanelerinde yattığı bilinmektedir (Bezirci 1974: 79). İşte bu kaldığı hapishane ortamları onun hikâyelerinde şu ya da bu şekilde vücut bulmuş, buralarda oluşan hafıza yazarın metinlerine farklı tonlarda ve zeminlerde girmiştir. Asım Bezirci'nin ifadesiyle "anı ile röportaj arası bir hikâye" olarak sayılabilecek "Şaka"da yazar, hapishanede yaşadığı bir olayı anlatır. Hikâyede iki ayrı olay sağlam olmayan bir şekilde birbirine bağlanmıştır. Olayın mekânı Konya mahpushanesidir. Mahpuslar arasında yer alan muhusabe-i hususiye memuru olan Cavit Bey'e anlatıcı bir şaka yapar. Bir hafta kadar önce salıverilen bir malmüdürünün ağzından yazılan bir tezkere gardiyanla gönderilir. Tezkereye göre, malmüdürünün dışarda öğrendiğine göre Cavit Bey’in sağllğı bozuk olduğu için tahliyesi düşünülmektedir. Samsun hapishanesine naklini isteyen Cavit Bey bu habere inanır ve sevinir. Fakat daha sonra işin aslı ortaya çıkıp, bunun bir şaka olduğu anlaşılınca Cavit Bey çok üzülür ve içine kapanır. Bu durum yazarı da üzüntüye sokar.

Sabahattin Ali'nin hapishane etrafında dönen hikâyelerinden birisi de "Çaydanlık"tır. Yazarın arkadaşlarının aktardığına göre, onun en sevdiği hikâyelerden birisidir bu. Hapishanedeki gözlemlerine dayanarak daha sonra yazıya geçirdiği bu öyküsünde hapishanenin revirinde yatan icra memuru Süleyman Efendi ile köylü Satılmış arasında geçen diyalog üzerine kuruludur. Süleyman Efendi yaşlı, geveze, ukala, çıkarcı, fesatçı bir tiptir. Satılmış ise tersine, sessiz, saf, iyi yürekli bir gençtir. Günde bir bardak çay karşllığında Süleyman Efendiye hizmet etmektedir. Süleyman Efendi bir gün aniden ölüverir. Akrabaları hapishaneye gelerek çaydanlığını ararlar, eşyalarını toplayıp giderler, ölünün gömülmesiyle de ilgilenmezler. Satılmış bu yaşananlara çok üzülür. Uzun zaman biriktirdiği otuz kuruşun yirmi kuruşunu alarak hademe İsmail'e uzatır. "Al şunu da sevaptır, bir testi alıver. Rahmetliyi mezarda kefensiz yatıracaklar, hiç olmazsa toprağına iki testi su döküver...” der.

Sabahattin Ali bu hikâyede köylünün bozulmamış, geleneğe bağlı kalan saf insanı Satılmış'a karşı, çürümüş kasabalı bir aydını Satılmış’ı koyar. Bozulmuş, çürümüş kasaba aydınının ismi bile dikkat çekicidir: Satılmış. Buna karşı köylü insanın temizliği, insancıllığı öne çıkartılır.

Yazarın hapishane ortamında hikâyesini dinleyerek eserlerinde işlediği isimlerden birisi de "Katil Osman”dır. Gerçekte katil olmayan Osman, "vururum, keserim!” sözlerini sürekli kullanmaktan dolayı adı katile çıkmış, ancak etrafta herkesin "Osman'da adam vuracak hal ne gezer!” diyerek eğlendiği bir isimdir. Osman bu eğlenmelerden kurtulmak için gerçekten günün birinde bir adamı vurarak öldürür.

16 Muhittin Doğan, “Gerçeklikten Kurmacaya Kelleci Mehmet Anlatıları”, Kurıkkale Üniversitesi Sosyal Bilimler Dergisi, Yıl 2016, Cilt 6, Sayı 2,, s. 342-359. 
Dolayısıyla "mahalle baskısı" denilebilecek bir psikoloji altında işlediği cinayetle hapse düşmüş bir mahkûmu anlatır. Hikâyenin son cümlesiyle "kimi adam öldürdüğü için katil diye anılır, kimi adı katile çıtı diye adam öldürür” (Sabahattin Ali, 1997: 164)

Sabahattin Ali daha genç yaşında soruşturmalara uğramış, devletin soğuk yüzü olarak ifade edilebilecek olan karakolla, mahkemelerle yüz yüze gelmiş bir isimdir. Onun hikâyelerinde bu deneyimlerin şu ya da bu şekilde metinlere yansıması da normaldir.

"Bir Firar"da o dönemde yaygın olan ve uygulanan dayakla ve işkence ile suçluyu ortaya çıkarma ya da suçu zorla kabul ettirme metodu anlatılır. Hukukta esas olan delilden hareketle suçluya ulaşmaktır. Ancak bu hikâyede önce suçlunun suçu kabul edilir, sonra deliller üretilir. Nihayetinde suçlu olduğu düşünülen İdris, işlemediği suçun cezasını hayatıyla öder (Sabahattin Ali, 1997: 95-98).

"Candarma Bekir" hikâyesi tamamen hapse düşen insanların dışarda iken başından geçenleri anlatmasından oluşur. Hikâye yazarın hapishanede Çallı Halil Efe'ye aldığı ceza için "Sana ne diye yüz bir sene verdiler? Ne haltlar karıştırdın?” sorusunu sık sık sorması ve nihayetinde onun geriye dönük olarak başından geçenleri anlatmasıyla oluşur. İşlediği bir cinayet sonrası hapse düşen Halil Efe, aslında hikâyenin adı da olan Candarma Bekir'le aynı mahalledendirler. Çocukluktan itibaren birbirini sevmeyen bu iki isim biri mahkûm, diğeri candarma olarak karşılaşmışlardır. Kara Murat'ın Bekir, eskiden kalan bu hınçla karakolda, Halil'i sevmeyen insanlara haber göndererek karakol önünde toplanmalarını sağlar ve onların gözleri önünde elleri kelepçeli olan Halil Efe'ye dayak atarak eziyet eder. Bu durum Halil Efe'nin çok zoruna gider. "Mahpuslukta adam dayak yemekten yllmaz." (Sabahattin Ali, 2007: 101) dedikten sonra esas zoruna gidenin ise, kendisini sevmeyen ileri gelenlerin ve muhtarların önünde dayak atılmasıdır. Bir cinayet işlediği için hapse düşen Halil Efe, aynı mahallede beraber büyüdüğü, ancak aralarının küçüklükten beri iyi olmadığı Candarma Bekir’i nasıl vurduğunu anlatmasiyla hikâye son bulur.

Yazarın öykü adları ve öykülerinde kullandığı isimler, onun metinlerini farklı okumalara, farklı yorumlamalar yapmaya imkân verecek niteliktedir. "Kazlar" hikâyesi de bunlardan birisidir. Anadolu insanının, kasaba ve köy hayatının bir parçası olan kaz, on yıl hapse mahkum olan Seyit'in cezaevi ortamının iyileştirilmesi için eşi Dudu'dan isteğidir. Hatta bir değil iki kaz istemiştir. Ancak tek kaza sahip olan Dudu, eşinin isteği komşulardan çaldığı diğer bir kazla tamamlamış, sonunda o da eşi gibi hapse düşmüş ve eşinin hapisteki ölümünü farklı yerlerde olduğu için öğrenememiştir.

"Kafakâğıdı" hikâyesi de yazarın hapishane hayatından izler taşıyan hikâyelerinden bir tanesidir. Çünkü hikâyenin daha giriş cümlesinde akşamüzeri hapishaneye bir sürü adam getirildiğinden bahsedildikten sonra "Bu kadar kalabalığı süngü takmamış iki candarmanın arasında yol parası borcundan buraya getirdiklerini anladık." (Sabahattin Ali 1997: 160) denilmektedir. Burada anlatıcının "anladık" fiilini kullanması yazarın buna tanık olduğu ve sonradan hikâyesini dinlediği konuları metnine taşıdığı sonucunu çıkartılabilir. Çünkü hikâyenin devamında gelen mahkûmların nizamiye içinde sıra sıra dizilmeleri, hangi koğuşa gidecekleri meselesinin uzun süre açıklığa kavuşmaması, kendi köylerinden mahpusların bu yeni gelenlere yaklaşması gibi ifadelerden bunlar anlaşılmaktadır. Hikâyede "yol parası" ödemediği için hapse düşen Mehmet’in yaşı seksen olmasına rağmen aynı adı taşıyan ölen torunun kimliğini taşıdığı için hapse atıldığı anlatılır (Güneş, 2017: 76).

Sabahattin Ali’nin hikâyelerini hapishane açısından iki başlık altında değerlendirmek mümkündür. Birincisi mahpusların dışardayken başlarından geçenleri anlattığı hikâyeler: "Bir Firar, Kafakâğıdı, 
Candarma Bekir, Katil Osman”. İkinci çeşit hikâyeleri ise hapishane içindeki serüvenleri ele aldıkları: "Kazlar, Bir Şaka, Duvar, Çaydanlık."

\section{Sonuç}

Modern Türk edebiyatının öncü isimlerinden birisi Sabahattin Ali, genç yaşlarında devletin soğuk yüzü olarak ifade edilen, mahkeme, cezaevi/hapishane gibi mekânlarla karşılaşmış ve ölümüne kadar da bu zaman zaman devam etmiştir. Toplumu ve dolayısıyla sosyal hayatı çok iyi gözlemleyen ve bunu da metinlerine taşıyan yazar, altmışa yakın kaleme aldığı hikâyesinin önemli bir kısmında hayatından izler taşıyan hapishanelere de yer vermiştir. Biyografik bir okumayla hikâyelerinde yer verdiği mahpushane izlerini iki başlık altında değerlendirmek mümkündür. Bunlardan bir kısmı yazarın mahkûm olmuş bir insan psikolojisi ile içerdeki insanın ruh dünyasını ve dışarıya bakışını anlatırken, diğer hikâyelerinde ise içerde iken etrafta gördüğü, başka mahkûmlardan hikâyesini dinlediği konuları metinleri arasına yaymasıdır. Ancak yazarı öne çıkartan ya da başarılı kılan bunları samimi bir dille ve gerçek tasvirlerle dile getirmesidir. Hikâyelerde anlatılan hikâye kahramanlarının önemli bir kısmının şu ya da bu şekilde aslında haksız şekilde hapse düşmüş olmaları da yazarın vermek istediği başka bir mesaj açısından önemlidir. Yanlış anlaşılmalara, adam kayırma ve iyi soruşturulmadan verilen mahkûmiyetler pek çok insanın hayatını karartmıştır.

Sabahattin Ali'nin hikâyeleri biyografi-yazar ilişkisi açısından okunduğu zaman zengin bir malzeme sunmakta sadece yazarın hayat çizgisindeki kırılmaları, değişmeleri anlamak açısından değil, Modern Türkiye’nin gelişim safhalarında hangi aşamalardan geçtiğini anlamak açısından da önemlidir.

\section{Kaynakça}

Ali, S. (1997). Bütün Öyküleri I Değirmen, Kağnı, Ses, İstanbul: YKY.

Ali, S. (1997). Bütün Öyküleri II Yeni Dünya, Strça Köşk, Esirler (Oyun), İstanbul: YKY.

Artvinli, F. (2013). Delilik, Siyaset ve Toplum: Toptaşı Bimarhanesi, İstanbul: Boğaziçi Ünviversitesi.

Atsız, N. (1944). "Başvekil Saraçoğlu Şükrü’ye İkinci Açık Mektup”, Orhun, S.16, 1 Nisan 1944, s.2-3.

Bahtin, M. (2017). Karnavaldan Romana: Edebiyat Teorisinden Dil Felsefesine Seçme Yazılar, çev. Cem Soydemir, 3. bs. İstanbul: Ayrıntı.

Baudrillard, J. (1995). Kötülüğün Şeffaflı̆ı: Aşırı Fenomenler Üzerine Bir Deneme, çev. Işık Ergüden, Emel Abora, İstanbul: Ayrintı.

Bezirci, A. (1974). Sabahattin Ali Hayatı-Hikâyeleri-Romanları, İstanbul: Oluş.

Bezirci, A. (1979). Sabahattin Ali Araştırma/Eleştiri, İstanbul: Gözlem.

Dinamo, H. İ. (2017). Musa'nın Hapishanesi, İstanbul: 2. Bs. Tekin.

Doğan, M. (2016). "Gerçeklikten Kurmacaya Kelleci Mehmet Anlatıları”, Krrıkkale Üniversitesi Sosyal Bilimler Dergisi, Cilt 6, Sayı 2, s. 342-359.

Ertüzün, R. M. (1985). Sabahattin Olayının Gerçeği (Benim Bildiğim Sabahattin Ali), İstanbul: Gür.

Erving, G. (2015). Timarhaneler: Akıl Hastalarını ve Kapatılmış Diğer Kişilerin Toplumsal Durumu Üzerine Denemeler, çev. Ebru Arıcan, Ankara: Heretik.

Esendal, C. K. (1966). "Sabahattin Ali Konusunda Aydınlığa Doğru”, Varlık, S. 671, 1 Haziran 1966, s.7. Filiz, A. ; Özkırıml, A. (1986). Sabahattin Ali, İstanbul: De.

Fındıklı, E. B. (2019). "Türkiye'de Cezaevi Mekanları, Edebiyat ve Çoklu Kronotoplar (1923-1953)", Türk - İslam Medeniyeti Akademik Araştırmalar Dergisi, Cilt /Volume: 14 - Say1 /Issue: 28 - s.321338. 
Foucault, M. (2015). Hapishanenin Doğuşu, çev. Mehmet Ali Kılıçbay, 6. basım, Ankara: İmge.

Foucault, M. (2016). Özne ve İktidar: Seçme Yazılar 2, çev. Işık Ergüden - Osman Akınbay, 5. bs. İstanbul: Ayrıntı.

Foucault, M. (2000). Büyük Kapatılma, çev. Işık Ergüden, Ferda Keskin, İstanbul: Ayrıntı.

Güneş, M. (2016). Sabahattin Ali’nin Eserlerinin Kaynakları Roma, Hikâye ve Şïrlerinde Biyografik Unsurlar, Ankara: Hece.

Hubard, P.; Kitchin, R. (2018). Mekân ve Yer Üzerine Büyük Düşünürler, çev. Emek Şevket Ataman, İstanbul: Litera.

Kısakürek, N. F. (2016). Cinnet Müstatili, Yılanlı Kuyudan, 19. bs. İstanbul: Büyük Doğu.

Korkmaz, R. (2016). Sabahattin Ali İnsan ve Eser, İstanbul: Kesit.

Lefebvre, H.( 2014). Mekanın Üretimi, çev. Işık Ergüden, İstanbul: Sel.

Omay, İ. S. (1947). Cezaevi (İş Esası Üzerine Kurulu), İstanbul: Cumhuriyet Matbaası.

Othmani, A. (2003). Hapishaneden Çıkış: Dünyadaki Cezaevi Sistemlerinde Reform Mücadelesi, hz. Sophie Bessis; çev. Işık Ergüden, İstanbul: Metis.

Proust, M. (2001). Kayıp Zamanın İzinde Mahpus, İstanbul: YKY.

Ran, N. H. (2016). Kemal Tahir'e Mahpushaneden Mektuplar, İstanbul: İthaki.

Sülker, K. (1968). Sabahattin Ali Dosyası, İstanbul: Ant.

Tahir, K. (1991). Notlar/195o Öncesi, İstanbul: Bağlam.

Taşan, B. (1976). "Sabahattin Ali Sinop’ta”, Soyut, S.87, Ocak 1976, s.44-45.

Ylldız, G. (1932). Hapishane Tetkikine Ait Rapor, Ankara: Umumi Hapishane Matbaası.

Ylldız, G. (2012). Mapushane: Osmanh Hapishanelerinin Kuruluş Serüveni (1839-19o8), İstanbul: Kitabevi. 